\title{
Global human rights obligations
}

\author{
Sigrun Skogly
}

\section{Introduction}

At the end of the cold war about 30 years ago, the international community experienced a brief period of reduced political conflict and a more conciliatory approach to international collaboration. The world returned to some of the visions that had inspired the establishment of the United Nations. These visions, as expressed through the Preamble of the UN Charter, reflected the conviction that peace and security in the world is dependent upon the universal respect for human rights and fundamental freedoms. However, the more conciliatory period was short-lived: the terrorist attacks on 9 September 2001, the subsequent international reactions in Afghanistan and Iraq, the global financial crisis in 2008/09, and other events have led to a far more polarised world where multilateralism and international cooperation have suffered. The four years of the Trump administration in the United States with its slogan 'America First' and disregard for international cooperation and institutions significantly increased tensions in the international community.

State practice related to human rights is often considered in light of big international events reflected above, or in the way individual states comply or ignore their human rights obligations. Often, the headlines are dominated by the situations where states fail to comply with obligations, or where they deny the existence of legal obligations. However, state practice also includes their behaviour in intergovernmental organisations, their bilateral interactions with other states, and their engagement with new soft and hard law developments.

It is against this backdrop that the current chapter will address global human rights obligations.

With the adoption of the UN Charter in 1945, human rights protection moved from being a national issue to a 'matter of legitimate international concern' (Vienna Declaration, para. 4). The experience of the Second World War made the drafters of the Charter recognise that certain human values were not adequately protected by individual states alone, but rather that the international community of states had a central role to play to ensure that individuals' human rights were protected. Despite the tensions in the international community described above, the global community of states is now more integrated than ever, and the changes in technology, population growth, depletion of natural resources, climate change, refugee flows, migration, and persistent poverty are current challenges that transcend national borders and require collective 
actions by states. These and other problems in the international community have had a significant impact upon individuals' ability to enjoy their human rights. Hence, global action to ensure respect for and promotion of human rights requires states to engage collectively.

The questions that will be addressed in this chapter are whether global human rights obligations exist; whether they are legally binding, and if so, what their content may be. In the discussion, the human rights framework can be considered 'a normative basis' (Pribytkova 2020b) for global obligations. From a moral philosophical perspective, it can be argued that all actors in the international community, including private enterprises and individuals, have obligations related to the human rights enjoyment of individuals globally (Pribytkova 2020a). However, this chapter will focus on states' obligations in this regard.

The chapter will address the definition and legal foundation for global obligations in Section 1. Section 2 will be devoted to a discussion of the content of the obligations, including the meaning of international assistance and cooperation, and how the tripartite classification of obligations to respect, protect, and fulfil may assist our understanding. Finally, Section 3 will address the question of causality and whether this is a useful concept for apportioning responsibility for human rights problems in the global community. The chapter concludes with some reflections on the challenges ahead for compliance with global human rights obligations.

\section{Section 1 - Definition and Legal Foundation}

In this chapter I will use the term 'global obligations' in the meaning of states' 'collective legal obligations' (Vandenhole 2018, p. 666) in the international community. Global obligations do not have an agreed definition, but for the purposes of the current work, I will use the term as expressed in the Maastricht Principles on Extraterritorial Obligations of states in the Area of Economic, Social, and Cultural Rights (Maastricht Principles):

Obligations of a global character that are set out in the Charter of the United Nations and human rights instruments to take action, separately, and jointly through international cooperation, to realize human rights universally.

(Principle 8(b))

Some will argue that extraterritorial human rights obligations in general, and 'global obligations' more specifically, represent a radical departure from the traditional human rights paradigm where states hold human rights obligations within their jurisdiction only (often equated with their physical territory). As is elaborated elsewhere in this volume, the question of jurisdiction and territoriality related to human rights obligations is a complex one, and much debate has been carried out amongst academics and other commentators. However, international actors, including human rights courts and treaty bodies, have accepted that jurisdiction and human rights obligations reach further than a state's territory. Nevertheless, global obligations have not been subject to adjudication in the same manner as states' individual extraterritorial obligations have been. Hence, the question of whether these obligations are legally binding has been debated.

To analyse the question of whether 'obligations of global character' are legally binding or merely an expression of moral principles, it is necessary to consider the sources from which these obligations arise.

It is clear that the Maastricht Principles are not legally binding per se; they are an expression of expert opinions regarding the status of extraterritorial human rights obligations in international law. Still, while the Principles themselves do not represent a separate source of law, 
they were explicitly 'drawn from international law [...] with a view to advancing and giving full effect to the object of the Charter of the United Nations and international human rights' (Maastricht Principles, Preamble). Consequently, Principle 8b refers to the UN Charter as the source of obligation, and this would be the starting point for an evaluation of the legal character of such obligations.

The central provisions in the UN Charter that provide for human rights protection are to be found in Article 1 that lists the purposes of the organisation, and more specifically in Article 1(3), which provides that

The Purposes of the Organisations are .... To achieve international co-operation in solving international problems of an economic, social, cultural, or humanitarian character, and in promoting and encouraging respect for human rights and for fundamental freedoms for all without distinction as to race, sex, language, or religion.

The obligations related to the purpose as detailed in Article 1(3) were further elaborated in Articles 55 and 56 of the UN Charter. These provisions hold that the member states of the UN 'pledge themselves to take joint and separate action in co-operation with the Organization [...]' to promote 'universal respect for, and observance of, human rights and fundamental freedoms for all $[\ldots]$ '.

In spite of the content of these provisions, some of the early commentators on the Charter held that the wording was ambivalent with the requirement of protecting human rights and fundamental freedoms, on the one hand, and the commitment to refraining from interference in domestic affairs on the other (UN Charter, art. 2(7)), and therefore the human rights provisions could not be seen as firm legal obligations (Kelsen 1951). Others held that the Charter imposed a legal duty on member states to respect and observe human rights and fundamental freedoms (Lauterpacht 1950).

Writing in 1965, Henkin argued that the provisions of the Charter were imprecise, and 'hortatory', trying to convince the member states of idealistic goals (Henkin 1965, p. 511). However, he conceded that

Article 1 proclaims international cooperation to promote human rights as one of the purposes of the United Nations; Articles 55 and 56 make the achievement of universal respect for human rights one of the few explicit undertakings of United Nations membership.

(Henkin 1965, p. 504)

Others have questioned the legal bindingness of the human rights provisions by pointing to the lack of international accountability structures in case states fail to comply with the provisions of the UN Charter (Langford 2013). However, it should be noted that the International Court of Justice (ICJ) in its Advisory Opinion on the Legal Consequences for States of the Continued Presence of South Africa in Namibia found that 'distinctions, exclusions, restrictions and limitations exclusively based on the grounds of race, colour, descent or national or ethnic origin [...] constitute a denial of fundamental human rights. This the Court views as a flagrant violation of the purposes and principles of the Charter of the United Nations' (ICJ 1971, para. 131). Consequently, the Court found the Charter to provide a source of law for international human rights obligations, and one to which member states of the UN could be held accountable.

It is important to take developments since the adoption of the United Nations' Charter into account. International human rights law has grown significantly in that time, and the understanding of its implications has deepened. This, combined with the recognition of human 
rights as an issue of legitimate international concern, as well as mainstreaming efforts of human rights throughout the UN system (UN Development Group's Human Rights Working Group), and initiatives such as the Responsibility to Protect (ICISS 2001), all point towards greater acceptance of the legal importance of the human rights provisions in the Charter.

Following the entry into force of the UN Charter, the Universal Declaration on Human Rights (UDHR) was adopted in 1948. This declaration provides a detailed interpretation of the content of the provisions in the UN Charter providing human rights protection (Stavrinides 1999). While focusing much on individual human rights, one article in the UDHR provides the goal for what global obligations should achieve. Article 28 states that 'Everyone is entitled to a social and international order in which the rights and freedoms set forth in this Declaration can be fully realized'. No individual state will be in a position to establish or create a 'social and international order', and the achievement of this is logically dependent on global cooperation. According to Eide, this article requires 'that social and international conditions be so structured as to make possible' the equal enjoyment of the rights provided in the UDHR (Eide 1999, p. 597). Consequently, Article 28 envisages a structure of the international community that is conducive to the full implementation and enjoyment of human rights, which reflects an obligation as per the United Nations' Charter.

These provisions in the Charter and the UDHR represent the foundation for global human rights obligations. As such, 'global obligations' have a raison d'être in themselves, namely an obligation for the states collectively to promote an international society that ensures the human rights enjoyment of individuals across the world. In operationalising this obligation, the attention has been given to international assistance and/or cooperation and how this shall be applied to achieve the human rights compliance. Practically, many commentators will translate global obligations to obligations of international (assistance and) cooperation (Pribytkova 2020b). Theo van Boven holds that 'human rights are placed by the Charter in a system of international cooperation' (van Boven 1997, p. 5). This international cooperation represents a state obligation to 'fulfil in good faith the undertakings they have assumed on the basis of the Charter of the United Nations and other relevant international instruments' (ibid). Consequently, the obligation of international cooperation becomes a means by which these obligations are implemented in a global setting.

Following the entry into force of the UN Charter and the adoption of the UDHR, global obligations have had their expression in individual human rights treaties, declarations, UN resolutions, and other soft law instruments. The requirement of international cooperation (and assistance) to achieve the full realisation of human rights has been explicitly recognised in many international human rights treaties inter alia in Article 2(1) of the Covenant on Economic, Social, and Cultural Rights (ICESCR), in the Preamble and Art. 4 of the Convention on the Rights of the Child (CRC); and the Preamble and Arts. 4 and 32 of the Convention on Rights of Persons with Disabilities (CRPD). In 1986, the UN General Assembly adopted the Declaration on the Right to Development (1986), which places the duty of international cooperation centrally in the text, for instance, in Articles 4 and 6. More recently, through the Millennium Declaration, and the Agenda 2030 with the Sustainable Development Goals, the UN General Assembly has adopted soft law instruments that reiterate the global commitments to cooperate for the promotion of human rights.

Furthermore, states have demonstrated that they accept human rights obligations stemming from the Charter and the UDHR, through the adoption of the Universal Periodic Review (UPR) procedure under the auspices of the Human Rights Council. The procedure was adopted by the General Assembly in 2006 (UN General Assembly Resolution 2006), when the Human Rights Council was established. Through this resolution, the General Assembly 
decided that the Council shall 'Undertake a universal periodic review, [...] of the fulfilment by each state of its human rights obligations and commitments in a manner which ensures universality of coverage and equal treatment with respect to all states' (UN General Assembly Resolution 2006, para. 5 (e)). The UN Charter and the UDHR represent the legal foundations for the mandate of this procedure, and all states members of the UN are subject to review under this procedure. The UN emphasises that the 'human rights obligations addressed are those set out in the UN Charter, the UDHR, and those pertaining to the treaties that each individual state has ratified, voluntary pledges and commitments, and relevant international humanitarian law' (Human Rights Council 2007, para. 1). Consequently, the obligations stemming from the UN Charter are global obligations to 'take joint and separate action' to promote 'universal respect for, and observance of, human rights and fundamental freedoms for all without distinction as to race, sex, language, or religion' (UN Charter, arts. 55 and 56) and are the foundations of the UPRs mandate.

To summarise, global human rights obligations have their legal foundations in the UN Charter, and have been further developed through subsequent international human rights instruments. These developments are clear expressions of state practice that confirm the global commitment to human rights protection. I will argue that to disregard the human rights obligations as provided in the Charter would weaken the legal significance of the whole treaty and put in doubt the other obligations it contains as well, such as the obligation to maintain international peace and security as provided in Article 1(1). Hence, all states that are members of the United Nations have ratified the UN Charter and committed to perform this treaty 'in good faith' (UN Vienna Convention on the Law of Treaties (VCLT), art. 26). Consequently, for the 193 states that are members of the United Nations, international cooperation to achieve the goals of the organisation is not a choice but a legally binding commitment that they have made (Salomon 2013a). The fact that states, particularly in the last 20 years, have been reluctant to expressly accept global human rights obligations does not remove the obligations based on international law. This reluctance reflects the difference between compliance with or breaches of international law obligations. Legal obligations entered into by ratifying treaties are not altered by states taking different views in different political realities. Furthermore, as has been argued above, state practice is expressed in different ways, and states' willingness to promote human rights through the United Nations' procedures and institutions contribute to their commitment.

\section{Section 2 - Content of Global Human Rights Obligations}

Having proposed that there is a firm legal foundation for global obligations in the UN Charter and subsequent treaties, the question to be addressed is what the content of these obligations are. In this section, I will discuss the concepts of international assistance and international cooperation and how they relate to each other. I will also apply the tripartite obligations' classification of respect, protect, and fulfil, to make the content of global human rights obligations more concrete.

\section{International assistance and cooperation}

On the basis of what has been discussed above, international assistance and cooperation are means by which the global human rights obligations can be complied with. This raises the question of the content of the requirements of international assistance and cooperation. The end goal of this cooperation is to comply with the global human rights obligations as set out 
in the UN Charter and confirmed through the International Bill of Rights. ${ }^{1}$ As not all forms of cooperation will necessarily be compliant with these obligations, there is a requirement of certain qualities of such cooperation (Skogly 2006).

The international instruments mentioned so far use two terms: international assistance and international cooperation. The UN Charter uses international cooperation, the International Covenant on Economic, Social, and Cultural Rights applies the term 'international assistance and cooperation' (ICESCR, art. 2(1)), while the Convention on the Rights of the Child and the Convention on the Rights of Persons with Disabilities both use the term 'international cooperation' (CRC, art. 4; CRPD, arts. 4 and 32). In the debate regarding the legal significance of these provisions, much of the attention has been given to whether they imply a legal obligation for richer countries to provide assistance to poorer countries. The obligation to provide international assistance has often been raised with respect to the commitment to allocate a minimum of $0.7 \%$ of GDP to development assistance, and whether this is a legal obligation or a political goal (Salomon 2013a). It has also been raised in terms of a possible legal obligation to provide disaster relief (Sandvik-Nylund 2003; UNCESCR, General Comment no. 14, para. 40), and more specifically to contribute to the development of scientific knowledge in developing countries (UNCESCR, General Comment no. 25), and to share such scientific progress.

In a world that is marked by global disparities related to human rights enjoyment and states' abilities to tackle these problems due to financial and structural impediments, the need for international assistance is evident. In addition to bilateral commitments, such international assistance is important on multilateral levels as means to implement global obligations. Hence, support for the UN Specialised Agencies and other global institutions that provide assistance necessary for the fulfilment of the substantive content of human rights is essential.

The UN Committee on Economic, Social, and Cultural Rights (CESCR) holds in its General Comment no. 3 that "the phrase "to the maximum of its available resources" [in Article 2(1)] was intended by the drafters of the Covenant to refer to both the resources existing within a state and those available from the international community through international cooperation and assistance' (CESCR, General Comment no. 3, para. 13). The Committee continues in the same General Comment to refer to Articles 55 and 56 of the UN Charter, and holds in paragraph 14 that 'international cooperation for development and thus for the realization of economic, social and cultural rights is an obligation of all states'. With this phrasing, the Committee clearly sees international cooperation as a means to be applied for human rights' realisation by all states members of the UN. This is important, as the General Comment in the next sentence refers to assistance as part of this international cooperation in holding that 'It is particularly incumbent upon those states which are is in a position to assist others in this regard' (ibid). Consequently, 'the reference to international assistance and cooperation has been understood by the UN treaty bodies as imposing an obligation for developing countries to seek, and for developed countries to offer, development assistance' (Vandenhole 2020, p. 227).

However, this discussion only addresses one element of 'international assistance and cooperation', and from the perspective of global obligations, perhaps not the most important one. International cooperation is so much more than international assistance, and the content of such international cooperation should have human rights as a primary objective to comply with the obligations stemming from the UN Charter. Writing from the perspective of the ICESCR, Sepúlveda holds that 'the purpose of the reference to international assistance and cooperation in the Covenant is to emphasise that such cooperation must be oriented, as a matter of priority, to the realization of all human rights, in particular economic, social and cultural rights' (Sepúlveda 2006, p. 275). Yet, we commonly see that international cooperation is not conducive to human rights compliance globally. The structures that underpin the international 
community's operation in today's globalised society are characterised by a 'particular model of the creation and distribution of wealth that is serving to enrich some, and not others' (Salomon 2007; Vandenhole 2018). A compelling example of this has been shown by Sekalala in addressing the right to health in the context of access to Anti-Retroviral Drugs for HIV/AIDs sufferers. She demonstrates clearly how the international law provisions relating to intellectual property in areas of global health are structured in manners that make it very hard for many developing countries to provide medication for their population and to comply with their obligations related to the right to the highest attainable standard of health (Sekalala 2017). In a series of reports, Inclusive Development International (IDI) demonstrates how the International Finance Corporation (The World Bank's private sector institution) has moved from direct loans to projects and programmes in developing countries, to using for-profit financial intermediaries. This has, according to IDI, led to great harm being inflicted upon people, and 'IFC intermediaries have financed companies that have forcibly evicted and impoverished hundreds of thousands of people. They have contributed to climate change, ravaged forests, polluted the oceans and rivers, and killed endangered species. Activists who have dared to resist them have been jailed, beaten and even murdered' (IDI, no date).

Such examples show that the quality of international cooperation is essential. The way in which states cooperate in areas such as trade, security, environment, and finance may contribute to human rights enjoyment, or it may be detrimental to human rights globally. Current structures and realities such as those detailed above are contrary to Article 28 of the UDHR as the 'social and international order' is not one in which 'the rights and freedoms in the Declaration can be fully realized' (UDHR, art. 28). To counter this reality, the Maastricht Principles prescribe that states, through international cooperation, must take 'deliberate, concrete, and targeted steps [...] to create an international enabling environment [to universally fulfil] economic, social and cultural rights' (Maastricht Principles, no. 29) by specifically mentioning areas of bi- and multilateral trade, investment, taxation, finance, environmental protection, and development cooperation. This demonstrates the point made above that the requirement for human rights conducive international cooperation relates to all areas where states cooperate internationally. This position has been confirmed by the CESCR, inter alia, in General Comment no. 14 on the right to health where it holds that "states Parties have an obligation to ensure that their actions as members of international organisations take due account of the right to health' (para. 39).

It was mentioned above that part of international assistance and cooperation is encouraged through the adoption of soft law instruments adopted by the member states of the UN. The most recent such instrument is the Agenda 2030 with its Sustainable Development Goals (UN General Assembly 2015). These Goals have been framed in language that incorporates references to human rights in that the Preamble holds that the Goals 'seek to realize the human rights of all', and the respect for human rights is mentioned on a few occasions (see inter alia paras. 3, 10, 19 and 35) in the Resolution introducing the SDGs. However, human rights provisions are not incorporated into the 17 Goals with their 169 targets, with the exception of one mention in Goal 4 on gender equality. Soft law instruments such as the SDGs may be part of the way in which states comply with their global human rights obligations (Sekalala 2017). However, to do so requires more than a brief mention of human rights, and that they recognise human rights requirements in a constructive manner by, for instance, including cross-cutting human rights principles of transparency, participation, non-discrimination, and accountability. As the SDGs currently stand, they give no clear indication as to how people can participate in the achievement of the Goals, or how they can hold anyone accountable for lack of progressive realisation of their rights through the fulfilment of the SDGs. It would lead too far in the present chapter to give a full assessment of these questions. However, there are a number of 
other soft law instruments that suffer from the same lack of specificity, and perhaps even more important, a specific recognition of the differentiated and/or collective responsibility for lack of compliance.

To summarise, the global human rights obligations are operationalised through international assistance and cooperation. Under the ICESCR, state Parties are under an obligation to seek assistance if necessary, and to provide assistance if able to. Obligations related to international cooperation involve quality criteria that require compliance with human rights standards, and in particular standards of economic, social, and cultural rights. As will be further elaborated in Section 3 below, it is important to recognise that states have global obligations whether or not they have the resources to contribute financially. Or in other words, the availability of resources is not 'an appropriate normative basis for allocating global obligations' (Pribytkova 2020a). In terms of global human rights obligations, international cooperation can be seen as an overarching principle, with international assistance as an element of such cooperation.

\section{Levels of obligations}

The tripartite classification of obligations to respect, to protect, and to fulfil human rights treaty provisions is now commonly accepted. These levels have been confirmed and detailed for extraterritorial human rights obligations (including global obligations) in the Maastricht Principles (Principle no 3). This tripartite classification relates to the negative and positive obligations states have to refrain from violating human rights and to take action to promote human rights.

The Maastricht Principles have detailed the content of the global obligations of states for all three levels in Principles 19, 23, and 28. Regarding the obligation to respect, it is confirmed that states have 'the obligation to refrain from conduct which nullifies or impairs the enjoyment and exercise of economic, social and cultural rights of persons outside their territories' (Principle 20). For global obligations, this would imply that international cooperation should be conducted in a way that is not harmful to human rights. The Commentary to the Maastricht Principles confirms that 'a state confronted with a situation that could implicate risks to economic, social, and cultural rights is required to undertake positive measures to ensure its actions do not nullify or impair the enjoyment of these rights outside the national territory' (de Schutter et al. 2012). This would be the case for states when carrying out bi- or multilateral international cooperation.

The obligation to protect with respect to extraterritorial obligations is framed in terms of the obligation to regulate the conduct of non-state actors over which states have regulatory authority (Principle 24). While much of the implementation of this obligation will relate to how states regulate the conduct of non-state actors over which they have direct legislative or other regulatory control, as part of their global obligations, states would also be expected to cooperate in international regulation of non-state actors to ensure that they 'do not impair the enjoyment of the economic, social and cultural rights of any person. This obligation includes measures to prevent human rights abuses by non-state actors, to hold them to account for any such abuses, and to ensure an effective remedy for those affected' (Principle 27). Furthermore, the Maastricht Guidelines on Violations of Economic, Social, and Cultural Rights confirm that 'the obligations of states to protect economic, social and cultural rights extend also to their participation in international organizations, where they act collectively' (Guideline no. 19). While these Guidelines come from soft law instruments, the CESCR has confirmed this principle in a number of General Comments. ${ }^{2}$ An example of how states can comply with their global obligations to protect would be to take an active and constructive part in the 
drafting process of the 'Legally binding instrument to regulate, in international human rights law, the activities of transnational corporations and other business enterprises', which is currently ongoing.

For global obligations, the Maastricht Principles are most detailed with respect to the positive obligation to fulfil (Principles 28-35). With clear reference to Article 28 of the UDHR, the Maastricht Principles - under the heading of 'Obligations to create an international enabling environment' - hold that states must take 'deliberate, concrete and targeted steps, separately, and jointly through international cooperation, to create an international enabling environment conducive to the universal fulfilment' of the relevant rights (Principle 29). In this Principle, it is also confirmed that such international cooperation is not only relevant for specific human rights programmes or human rights cooperation, but rather that this action includes 'matters relating to bilateral and multilateral trade, investment, taxation, finance, environmental protection, and development cooperation'. Consequently, the global human rights obligation to fulfil is clearly comprehensive and touches all forms of international cooperation amongst states. The list provided of areas where this obligation is relevant is not exhaustive, but rather indicative, and other areas may well be equally relevant (de Schutter et al. 2012, p. 1148). The CESCR has also confirmed that the obligation to create an international enabling environment would include addressing structural causes for human rights problems internationally, such as structural causes of food crises and the 'underlying causes of food insecurity, malnutrition and undernutrition' (UNCESCR, statement 2008, para. 12).

Thus, the Maastricht Principles detail the content of global human rights obligations, and in particular to the obligation to fulfil. The detailing of global obligations makes it clear that they set a quality marker on all international cooperation, not only cooperation that is undertaken specifically in the name of human rights promotion. Much of the content of the provisions of the Maastricht Principles relates to the way in which states should carry out their international cooperation, and as such this reflects obligations of conduct (UNCESCR, General Comment no. 3). However, as has been shown, the international cooperation is aimed at certain goals that reflect the quality of the cooperation. This requirement for a certain level of quality is determined by the impact (positive and negative) on human rights enjoyment of international cooperation among states, and as such represents obligations of result (Skogly 2006).

\section{Section 3 - Causality and Equal or Differentiated Responsibilities}

The above sections have addressed the legal foundations for global obligations and detailed how we understand the content of these obligations. What will be considered in this section is the question of responsibility related to global non-fulfilment of internationally guaranteed human rights. The Maastricht Principles have been criticised for not providing a clear division of responsibility between states individually and collectively, as they do not 'establish a regime of shared responsibility for violations of the global obligations' (Vandenhole 2018, p. 666). This shows that the Maastricht Principles were not able to develop the accountability principles that, according to some commentators, were missing already from the UN Charter. The clarification of shared responsibility for collective global obligations is therefore still an important task to enable better accountability for states' failures to provide an international enabling environment for human rights enjoyment. If global human rights obligations are obligations that states hold collectively, does this mean that the responsibility for actions and omissions to ensure that the rights are respected, protected, and fulfilled are equally distributed? Commonly when states violate human rights provisions to which they are bound through international legal provisions, they may (dependent upon acceptance of certain procedures) be held responsible through a 
variety of national and international accountability mechanisms. In this respect, for traditional human rights litigation, the question of causality is central: has the state caused the human rights problem, or could they have prevented the human rights problem through regulation or other forms of due diligence? In order to determine the causal link between state acts or omissions and a human rights violation, it is necessary to determine which acts or omissions that led to the human rights breaches. It is also necessary to identify the international legal obligations that made the acts or omissions unlawful (Vandenhole 2018). However, establishing such levels of causality is rarely easily done with respect to the collective legal obligations of states (Skogly 2013). When states work together in international cooperation, the individual responsibility for the negative outcome of such cooperation is hard to assign. Salomon holds that

To ignore the legal implications of the need for remedial international action would be to hollow out the value of the positive obligation of international cooperation for the realisation of socio-economic rights completely. It is difficult, however, to determine when an obligation of international assistance and/or cooperation has been breached, thereby giving rise to a claim of international legal responsibility, because there is a paucity of judicial elucidation as to what would indicate that a given state was required to act in this area.

(Salomon 2013b, p. 279)

However, the fact that it is harder to establish a causal link between an act or omission when states act through international cooperation, and that act/omission leads to human rights violations, does not mean that global human rights obligations do not exist or should not be complied with. ${ }^{3}$ Salomon argues that 'states acting singly or jointly need not have caused harm in order to be under a positive duty to address the nonfulfillment of socio-economic rights elsewhere, nor in order to be held responsible for an internationally wrongful act derived from a failure to comply with an obligation to assist or cooperate internationally' (Salomon 2013b, p. 281).

While all states have obligations based on the legal sources discussed in Section 2 above, and these obligations reflect negative and positive obligations based on the principles of respect, protect, and fulfil human rights, it is not a given that the content of these obligations is equal for all states in the international community. Will the responsibility for rectifying problems be the same for Mali or Fiji as it is for the United States or for Germany? While the UN Charter Article 2(1) clearly recognises each state's sovereign equality in the international community, it does not necessarily imply that all states have equal amounts of obligations globally. Or put differently, states - depending on their size (territory, population, economy) - may be affecting the lives and living conditions of individuals around the world in different ways, and therefore the actual content of a state's obligation may differ. Other elements that may come into consideration are a state's history, economic power, contribution to problems, and its ability to influence decision-making in international institutions. As an example, it is clear that the five permanent members of the UN Security Council have more power to influence international action/inaction that can affect individuals' enjoyment of human rights than do other UN member states. Less formalised influence distinguishers can also be found in factors such as a state's history as a colonial power, military capabilities, or host to large multinational corporations. In short, states are different in terms of their abilities to influence state and non-state actors (including influence over institutions such as the International Monetary Fund, the World Bank, and the World Trade Organisation), and those states that have the opportunity should 'exercise such influence, in accordance with the Charter of the United Nations, and general international law [...]' (Maastricht Principles, no. 28). In addition to differentiation in 
influence or power, there are also differences in terms of benefiting from a system that perpetuates inequalities (Salomon 2007).

Reflecting these differences, principles have developed whereby obligations can be considered through a lens of 'common but differentiated responsibility' (CBDR) (Vandenhole 2018, p. 662). With origins in international environmental law (Shelton 2009), this principle recognises that states' history and ability to influence differ. Shelton holds that the CBDR principle 'provides a corrective justice basis for obliging the developed world to pay for past harms as well as present and future harms' (ibid, p. 67). Writing in the context of international environmental law, she argues that 'even though the responsibility for protecting the environment is to be shared among all nations, countries should contribute differently to international environmental initiatives depending on their capabilities and responsibilities. Common but differentiated responsibility calls broadly for developed countries to take the lead in solving existing global environmental problems, in particular because of their contributions to the creation of these problems' (ibid).

Salomon addresses the CBDR principle from a global obligation for international human rights perspective and holds that

While all states are to cooperate in order to contribute to the common objective of eradicating world poverty, the responsibility of a state for the creation of a just institutional economic order should be in accordance largely with its weight and capacity in the world economy.

(Salomon 2007, p. 193)

She continues that in the context of international cooperation for human rights the CBDR 'provides the basis for four indicators that may assist in determining responsibility [...]', which can be summarised as: a) the contribution that a state has made to the emergence of the problem; b) the relative power of influence a state has at the international level over the direction of finance, trade, and development; c) whether the given state is in a position to assist; and d) determination of which states benefit most from the existing distribution of global wealth and resources (ibid).

Thus, the arguments based on the CBDR are not based on an assessment of the direct causality between a state's action and the resulting human rights problems. As has been indicated, global human rights obligations that are implemented through international assistance and cooperation do not lend themselves easily to a direct causality relationship. Under human rights obligations, states have a negative duty to refrain from deteriorating the human rights situation and a positive duty to work for the improvement of human rights globally (Maastricht Principles, no. 28). Such obligations are not dependent upon establishing an individual state's responsibility for causing the human rights problem in the first place (Salomon 2013a). The CBDR principle is a way in which equity can be addressed, whereby historic influence as well as ability to contribute is taken into account (Shelton 2009).

On the other hand, the CBRD principle does not remove the obligations for financially poorer and less influential states. Constructive cooperation to avoid human rights problems will not necessarily require resources more plentiful in developed countries, but rather a political will to make decisions that are conducive to an improved international environment for human rights protection and enjoyment. As already mentioned, availability of resources is not a basis for allocation of obligations but may be a basis for ability to contribute. The ability to influence differs among states, both from a de facto and a de jure perspective. In the Security Council, the five permanent members have veto powers that no other members of the United Nations have, 
and consequently they have more responsibility than other states to engage constructively in international cooperation to carry out the UN mandate. Furthermore, in certain international institutions such as the World Bank and the International Monetary Fund, the member states have weighted voting power based on their financial contributions to the institutions. Hence, the greater financial powers (such as the G7) have significantly more influence on the policies and programmes that the institutions pursue. ${ }^{4}$ From a CBDR perspective, the dominant states in these institutions would have more responsibility for furthering human rights constructive international cooperation in these institutions.

\section{Conclusions}

In this chapter, the legal foundations for global human rights obligations have been discussed. Stemming from treaty obligations undertaken by the member states of the United Nations, it is concluded that the global human rights obligations as reflected in the Charter's Articles 1(3), 55, and 56 are legally binding. These provisions of the Charter have been followed by a significant development in human rights law and practice that support this conclusion.

The chapter details the content of global human rights obligations and argues that the sources of such obligations are to be found in the UN Charter and subsequent international human rights law. The Charter requires that ratifying states comply with the overall global obligations as detailed in its provisions, while international assistance and cooperation are means through which these obligations can be implemented. Furthermore, the content of the obligations has been analysed from the tripartite classification perspective of respect, protect, and fulfil.

One of the remaining difficulties that needs further elaboration is the question of apportioning of responsibility among states in the international community. It is argued that states do not have equal obligations when it comes to international assistance and cooperation. Related to assistance, it is a matter of which states have the ability to assist; related to international cooperation, the responsibility is heavier for those states that are in a position to influence. In the discussion of these matters, the principle of 'common but differentiated responsibility' is helpful in explaining how the differences may be addressed.

In terms of state practice, it is important to consider this from three distinct perspectives: the firm legal commitments stemming from ratification of international treaties, such as the UN Charter and international human rights law conventions and covenants; the political commitments states make in international fora, such as the UN General Assembly; and finally, the behaviour between and among states in other bi-and multilateral relations. While it is easy to find examples where states do not behave in a manner consistent with their global human rights obligations, it has been argued above that this does not imply that obligations do not exist, but rather that such behaviour represents non-compliance, or breach, of the obligations. Furthermore, the contribution to the compliance with global obligations through participation in international fora should not be underestimated. Soft law instruments emerge from such activities, for example, the Sustainable Development Goals, or the Responsibility to Protect principles. Such soft law instruments are expressions of states' political will to further human rights conducive global initiatives and strengthen the commitment to the content of global obligations. Still, such initiatives and soft law instruments need to be critically analysed and potentially improved to ensure that the cross-cutting human rights principles (participation, transparency, non-discrimination, and accountability) is brought to bear, and that the focus remains on the individual person who may or may not have their human rights situation improved through international assistance and cooperation. 


\section{Notes}

1. The International Bill of Rights is a common label for the Universal Declaration on Human Rights and the two International Human Rights Covenants from 1966.

2. See for example, UN CESCR General Comment no. 12 (1999), para. 38; UN Human Rights Committee (HRC), CCPR General Comment No. 25, art. 25 (Participation in Public Affairs and the Right to Vote), The Right to Participate in Public Affairs, Voting Rights and the Right of Equal Access to Public Service, 12 July 1996, CCPR/C/21/Rev.1/Add.7, para. 77.

3. It should be noted that much of international cooperation that states take part in is conducted through international institutions, such as the United Nations, the World Bank, or NATO. This institutional construct adds to the complexity in apportioning responsibility, as such international institutions composed of states are also separate legal entities with their own responsibilities. However, the division of responsibility between the member states and the international institutions is not the focus of this article. In this chapter, the attention is devoted to the role of the state in international cooperation, and even if the institutions themselves may have responsibilities, that does not mean that individual states working collectively will lose their original human rights obligations.

4. The G7 consists of Canada, France, Germany, Italy, Japan, the United Kingdom and the United States. The G7 represent $41.26 \%$ of all the cotes in the IMF; The United States having $16.5 \%$ on their own.

\section{References}

De Schutter, et al. (2012) 'Commentary to the Maastricht Principles on Extraterritorial Obligations of States in the Area of Economic, Social and Cultural Rights', Human Rights Quarterly 34(4), 1084-1169.

Eide, A. (1999) 'Article 28' in Alfredsson, G. and Eide, A. The Universal Declaration of Human Rights: A Common Standard of Achievement, Martinus Nijhoff Publishers.

Henkin, L. (1965) 'The United Nations and Human Rights', International Organisation 19(3), 504-517.

Inclusive Development International (2020) 'Outsourcing Development - Lifting The Veil On The World Bank Group's Lending Through Financial Intermediaries’, https://www.inclusivedevelopment.net/ what-we-do/campaigns/outsourcing-development/ [accessed 12 February 2021].

International Commission on Intervention and State Sovereignty (2001) 'The Responsibility to Protect', December 2001. The Responsibility to Protect: Report of the International Commission on Intervention and State Sovereignty, 2001 - Global Centre for the Responsibility to Protect (globalr2p.org) [accessed 18 July 2021]

International Court of Justice (ICJ) (1971) 'Advisory Opinion on the Legal Consequences for States of the Continued Presence of South Africa in Namibia', 21 June 1971, Judgments, Advisory Opinions and Orders | International Court of Justice (icj-cij.org) [accessed 18 July 2021]

Kelsen, H. (1951) The Law of the United Nations, Stevens and Sons.

Langford, M. et al. (eds). (2013) Global Justice, State Duties, Cambridge University Press.

Lauterpacht, H. (1950) International Law and Human Rights, Stevens and Son.

Maastricht Principles on Extraterritorial Obligations of States in the Area of Economic, Social and Cultural Rights (2011) 'Maastricht Principles on Extraterritorial Obligations of States in the Area of Economic, Social and Cultural Rights', https://www.etoconsortium.org/nc/en/main-navigation/library/ maastricht-principles/?tx_drblob_pi1\%5BdownloadUid\%5D=23 [accessed 12 February 2021].

Pribytkova, E. (2020a) 'What Global Obligations Do We Have?', Chicago Journal of International Law 20(2), 384-449.

Pribytkova, E. (2020b) 'Global Obligations for Sustainable Development: Harmonizing the 2030 Agenda for Sustainable Development and International Human Rights Law', University of Pennsylvania Journal of International Law 41, 1031-1136.

Salomon, M.E. (2007) Global Responsibility for Human Rights, Oxford University Press.

Salomon, M.E. (2013a) 'From NIEO to Now and the Unfinishable Story of Economic Justice', International and Comparative Law Quarterly 62, 31-54. 
Salomon, M.E. (2013b) 'Deprivation, Causation and the Law of International Cooperation' in Langford, M. et al. (eds). Global Justice, State Duties, Cambridge University Press.

Salomon, M.E. (2014) 'How to Keep Promises: Making Sense of the Duty Among Multiple States to Fulfil Socio-Economic Rights in the World', SHARES Research Paper 53, SHARES-RP-53-final.pdf (sharesproject.nl) [accessed 18 July 2021]

Sandvik-Nylund, M. (2003) Caught in Conflicts: Civilian Victims, Humanitarian Assistance and International Law, Åbo, Institute for Human Rights.

Sekalala, S. (2017) Soft Law and Global Health Problems: Lessons from Responses to HIV/AIDS, Malaria and Tuberculosis, Cambridge University Press.

Sepúlveda, M. (2006) 'Obligations of "International Assistance and Cooperation" in an Optional Protocol to the International Covenant on Economic, Social and Cultural Rights', Netherlands Quarterly of Human Rights 24(2), 271-303.

Shelton, D. (2009) 'Describing the Elephant: International Justice and Environmental Law' in Ebbesson, J. and Okowa, P. Environmental Law and Justice in Context, Cambridge University Press.

Skogly, S. (2006) Beyond National Borders: States' Human Rights Obligations in International Cooperation, Intersentia.

Skogly, S. (2013) 'Causality and Extraterritorial Human Rights Obligations' in Langford, M. et al. (eds). Global Justice, State Duties, Cambridge University Press.

Stavrinides, Z. (1999) 'Human Rights Obligations under the United Nations Charter', The International Journal of Human Rights 3, 38-48.

UN Committee on Economic, Social and Cultural Rights (CESCR) (1990) GC 3 on the Nature of States Parties' Obligations (Art. 2, Para. 1, of the Covenant), 14 December 1990, E/1991/23. (1999) GC 12 on the Right to Adequate Food (Art. 11 of the Covenant), 12 May 1999. (2000) GC 14 on the Right to the Highest Attainable Standard of Health (Art. 12 of the Covenant), 11 August 2000, E/.12/2000/4.

(2008) World Food Crisis: Statement, 20 May 2008, UN Doc. E/C.12/2008/1.

(2020) GC 5 on science and economic, social and cultural rights (article 15 (1) (b), (2), (3) and

(4) of the International Covenant on Economic, Social and Cultural Rights, 30 April 2020, E/C.12/ $\mathrm{GC} / 25$.

UN Committee on Human Rights (HRC) (1996) CCPR GC 25 on Article 25 (Participation in Public Affairs and the Right to Vote), The Right to Participate in Public Affairs, Voting Rights and the Right of Equal Access to Public Service, CCPR/C/21/Rev.1/Add.7.

UN General Assembly (UNGA) (1966) International Covenant on Economic, Social and Cultural Rights, United Nations Treaty Series, 16 December 1966, 993.

(1986) Declaration on the Right to Development: resolution/adopted by the General Assembly, 4 December 1986, A/RES/41/128.

(1989) Convention on the Rights of the Child, United Nations Treaty Series, 20 November 1989, vol. 1577.

(1993) Vienna Declaration and Programme of Action, 12 July 1993,A/CONF.157/23.

(2006) Resolution, 15 March 2006, UN Doc A/RES/60/251.

(2007) Convention on the Rights of Persons with Disabilities: resolution/adopted by the General Assembly, 24 January 2007, A/RES/61/106.

(2015) Transforming our world: the 2030 Agenda for Sustainable Development, 21 October 2015, A/RES/70/1.

United Nations, Human Rights Council, Basic Facts about the UPR, https://www.ohchr.org/EN/HRBodies/UPR/Pages/BasicFacts.aspx

United Nations, Human Rights Council, Institution-building of the United Nations Human Rights Council, 18 June 2007, A/HRC/RES/5/1(1).

United Nations (UN) (1986) Charter of the United Nations, 1 UNTS XVI.

(1996) Vienna Convention on the Law of Treaties, United Nations Treaty Series, vol. 1155. 
University of Minnesota Human Rights Library (1997) 'Maastricht Guidelines on Violations of Economic, Social and Cultural Rights', adopted by a group of experts in 1998, http://hrlibrary.umn.edu/instree/ Maastrichtguidelines_.html [accessed 18 July 2021]

van Boven, T. (1997) 'Introduction' in United Nations. Manual on Human Rights Reporting, UN doc. no. HR/PUB/91/1 (Rev.1).

Vandenhole, W. (2018) 'De-Growth and Sustainable Development: Rethinking Human Rights Law and Poverty Alleviation', Law and Development Review 11(2), 647-675.

Vandenhole,W. (2020) 'Towards a Division of Labour for Sustainable Development: Extraterritorial Human Rights Obligations' in Kaltenborn, M. et al. (eds). Sustainable Development Goals and Human Rights (Interdisciplinary Studies in Human Rights, 5), Springer. 